\title{
An Analysis of Students' Mastery of Vocabulary
}

\author{
Desi Andriani ${ }^{1)}$, Vera Sriwahyuningsih ${ }^{2)}$ \\ ${ }^{1}$ Universitas Putra Indonesia YPTK Padang \\ Desiandriani343@yahoo.com \\ ${ }^{2}$ Universitas Putra Indonesia YPTK Padang \\ Verasriwahyuningsih93@gmail.com
}

\begin{abstract}
Vocabulary is an important thing in English. Therefore, at university vocabulary is a compulsory subject for English language study program. Students cannot speak, write, listen, and read the reading texts when they do not have enough vocabulary to understand them. Thus, students should master vocabulary. The research is a descriptive one. Population is students of UPI YPTK Padang in 2018/2019 academic year. The sample of the research is students of English education faculty. They were thirty four students. The data were collected by using test and questionnaire. The test is given to know students' ability in vocabulary mastery. It consists of thirty questions. It consists of matching test for giving definition of a word, filling blank space and finding new vocabularies from unarranged letters. The result of the test showed that different abilities of students in mastery vocabulary. The students can find new vocabularies from unarranged letters. This was an interesting activity for them. Then, in matching the vocabularies to the definitions or synonyms, the students also could do it. The questionnaire proved that students have good ability in mastery vocabulary but they have some difficulties related to the some aspects such as grammar and spelling.
\end{abstract}

Keywords: difficulties, mastery, vocabulary 


\section{INTRODUCTION}

English is a subject at university. The purpose of English at university is not only to give skill to the students, but also to help students to find or to get a job after they graduated later. Since English is an international language. Skill of English is very important for the students because they are as academic person needs more knowledge to face globalization era. English has any important parts. They are skills and language components of English. Skills of English are speaking, reading, writing and listening. Language components of English are vocabulary, grammar, pronunciation and spelling. Between skills and language components are supported each other. They also cannot be separated each other.

One of language components is vocabulary. Vocabulary is a key of English. Someone cannot speak, write, listen and read if she/ he does not have vocabulary. In vocabulary class, students learn vocabularies of English. They give many vocabularies of sports, school objects, household objects, part of plants, tree, volume, etc. The purpose is to make the students can use the vocabularies in their daily life, since vocabularies is an important thing in communication. As stated by Moeller et al (2009: 2) vocabulary is central to the learning of foreign language includes literature, music and content knowledge.

At university especially for English study program, vocabulary is a compulsory subject. But, based on writer preliminary observation, at UPI YPTK Padang students still have low ability in vocabulary. Students will not understand the text if they do not have vocabulary. Students also cannot speak if they do not have vocabulary. Moreover, the fact in the classroom showed that students still have problems and difficulties in identifying the vocabularies. They still doubt in identifying which one of adverb, verb, adjective and noun.

There are two research questions that answered through this research. They are: what are the students' problems in vocabulary mastery at English study program of UPI YPTK Padang? And what are the factors influence the students' problems in vocabulary mastery at English study program of UPI YPTK Padang? Then, there are two purposes of this research. They are: to find out students' problems in vocabulary mastery of English study program of UPI YPTK Padang and to find out factors caused students' problems in vocabulary mastery of English study program of UPI YPTK Padang

There are some definitions of vocabulary. Faraj (2015: 10) says that vocabulary is an essential building block of language and as such it makes sense to be able to measure learners' knowledge of it. Therefore vocabulary is one of the most pivotal components of language learning and teaching of a foreign language since it affords learner of the language access to all forms of oral and written communication of word. Moreover, Alqahtani in Cameron (2001) defines that vocabulary as one of the knowledge areas in language, plays a great role for learners in acquiring a language. In line to Alqahtani, Nagy (1997) argues that vocabulary knowledge is fundamental to comprehending text. Hudson (2007) defines that vocabulary knowledge is a key element to better reading comprehension. Then, 
Nation (1990) defines that vocabulary plays a great role predictor of overall reading ability.

Vocabulary learning plays an important role in foreign language learning, both in the first language and second language. According to Kamil and Heibert in Ahmadi et al (2005: 187) vocabulary is as knowledge of words or word meaning. Moreover, Ling et al (2012: 55) also suggest that the vocabulary also should introduce from the simple to the complex one. They also suggest that to the author to make the meaning of the vocabulary can be guessed by the students without look dictionary. So, students get new vocabularies during the learning. The text should allow students to make inference, apply what they read in their real life, identify meaning of unknown words from the context, replace difficult words with the simpler words and new words are repeated for reinforcement.

Vocabulary is central to English language teaching because without sufficient vocabulary students cannot understand other or express their own ideas. Wilkins (1972) states that while without grammar very little can be conveyed, without vocabulary nothing can be conveyed. Moreover Albeit in Faraj (2015: 11) defines that vocabulary is not the only element that convey meaning, but also there are some other vital feature like grammar, intonation, stress, tone of voice, rhythm, pauses, silences or hesitations, etc. McCathy (1990) argues that no matter how well the students learns grammar, no matter how successful the sounds of second language are mastered, without words to express a wide range of meanings, communication in a second language just cannot happen in any meaningful way. It can be concluded that vocabulary is a very important part of language. Especially for teaching and learning process, vocabulary plays an important role. Therefore, students should be master as many as possible vocabularies.

Vocabulary is one of the difficult subjects and students have problems in mastery vocabulary because vocabulary skill includes some aspects. According to Cameron (2001: 78) vocabulary skill included: pronunciation, spelling, grammar and meaning.

1. Pronunciation

Pronunciation is one of the aspects that have a great influence of vocabulary. Pronunciation is the way in which a particular person pronounces the word of a language. Students need to listen a new word in foreign language in order they can notice the sound at the beginning and at the end, the stress patterns of the word. There is different pronunciation between English and Indonesian vocabularies. Every language has special phoneme, English has different sound with Indonesia/ Malaysia sound. Therefore, students have problems in pronunciation. The students have difficulties for some reasons. The first reason is that some sounds of English do not exist in Indonesia. The phoneme /o/ (thin) and $/ \Theta /$ (this) are found, it is not found in Indonesia. Therefore, in learning pronunciation, one must learn or not only to form sound correctly but also to use them in the correctly place. 


\section{Spelling}

Students need to know the letters and syllables that make up the word that is called spelling. Spelling is the act of forming words correctly from individual letter or the way that a word is spelt. Sound-spelling mismatches are likely to be the cause of errors; either of pronunciation or of spelling and can contributes to a word's difficulty. While most of English spelling is fairly lawabiding, there are also some glaring irregularities.

\section{Grammar}

Also problematic is the grammar associated with the word, especially if his differs from mother language equivalent. Remembering whether a verb enjoy, love, or hope is followed by an infinite (to swim) or an -ing form (swimming) can add to is difficulty.

\section{Meaning}

When two words overlap in meaning, learners are likely to confuse them. Make and $d o$ are a case in point.

5. Range, condition and idiomatic

\section{METHOD}

The method of this research is a descriptive research. Gay and Airasian (2000) state that descriptive research determines and reports the ways thing are. It is told about something occurs in the field. Further, Gay and Airasian also add there are two reasons why people use the descriptive method. First, a high percentage of reported research studies are descriptive in nature. Second, the descriptive method is useful for investigating a variety of educational problems. Since it is a descriptive research, the data were collected through test.
This research was taken at English study program of UPI YPTK Padang. The location is on Jalan Lubuk Begalung Padang, Sumatera Barat province. The research was taken at second semester on 2018/2019 academic year.

This research was used descriptive method. This research described the object of the research and described them systematically and accurately.

\section{Population}

Sugiyono (2010: 117) defines that population is a generalization region consisting of objects or subjects that have certain qualities and characteristics are determined by the researcher to be studied and then make conclusion. In this research, the population is total number of students of English study program of Universitas Putra Indonesia YPTK Padang.

Sample

Best and Kahn (1995: 13) defines that a sample is a small proportion of population selected for observation and analysis. This statement means that sample is part of individual members which is chosen to represent of the whole population. In this research, the sample is second semester students of English language study program of UPI YPTK Padang. The sample is thirty four students. The sampling used is total sampling.

The data collected through test and questionnaire.

Test

Arikunto (2006: 193) argues that instrument is a tool or facility that is used by researcher to collect data in order to get better result. There are two kinds of instruments. They are test and non test instrument. This research 
used test as instrument. The purpose is to get the data about students' mastery of vocabulary. The test is matching and finding vocabularies from unarranged letter. The test consists of thirty questions.

\section{Questionnaire}

Sudijono (2007: 84) states that questionnaire has forms such as multiple choice item and Likert Scale. Gay (2000: 156) states that a likert scale ask participant to respond a series of statement, they were strongly agree (SA), agree (A), undecided (U), disagree (D) or strongly disagree (SD) with each statement. The instrument consists of several items that express students' mastery of vocabulary. The score of questionnaire will give based on the type of each item. The score arranged: $\mathrm{SA}=5, \mathrm{~A}=4, \mathrm{U}=3, \mathrm{D}=2$, $\mathrm{SD}=1$.

\begin{tabular}{|c|c|c|}
\hline \multirow[t]{2}{*}{ Categories } & \multicolumn{2}{|c|}{ Score of Statement } \\
\hline & Positive & Negative \\
\hline Strongly & 5 & 1 \\
\hline $\begin{array}{l}\text { Agree } \\
(\mathrm{SA})\end{array}$ & & \\
\hline Agree (A) & 4 & 2 \\
\hline $\begin{array}{l}\text { Undecided } \\
\text { (U) }\end{array}$ & 3 & 3 \\
\hline $\begin{array}{l}\text { Disagree } \\
\text { (D) }\end{array}$ & 2 & 4 \\
\hline $\begin{array}{l}\text { Strongly } \\
\text { Disagree } \\
\text { (SD) }\end{array}$ & 1 & 5 \\
\hline
\end{tabular}

The data that were analyzed are data from test and questionnaire. The data analyzed through some steps:

a. Analyzing students' score of vocabulary mastery test. This is analyzed to know students' level of vocabulary mastery.

b. Identifying students who get problems in vocabulary mastery

c. Combining the result of test and questionnaire

d. Making conclusion.

\section{FINDINGS AND DISCUSSION}

Based on the data analysis, the scores are:

1. Grammar

The result of questionnaire shows the indicator grammar

Table 2. Result of questionnaire about grammar

\begin{tabular}{cccc}
\hline $\begin{array}{c}\text { Score } \\
\text { interval }\end{array}$ & Category & Frequency & $\begin{array}{c}\text { Perce } \\
\text { ntage }\end{array}$ \\
$\geq 33$ & $\begin{array}{c}\text { Strongly } \\
\text { agree }\end{array}$ & 2 & 2.94 \\
$27-32$ & $\begin{array}{c}\text { Agree } \\
21-26\end{array}$ & 16 & 41.18 \\
$15-20$ & Undecided & 16 & 52.94 \\
$\leq 14$ & $\begin{array}{c}\text { Disagree } \\
\text { Strongly } \\
\text { disagree }\end{array}$ & 0 & 2.94 \\
Total & 34 & 0 \\
\hline \multicolumn{4}{c}{} \\
\end{tabular}

The table shows students' problem in mastery vocabulary in indicator grammar is categorized good enough. This is because students still have problems in categorizing the words. For example statement of the questionnaire 'I am able to mastery vocabulary especially adjective'. In this statement, students gave agree respond. It means that they are able to mastery vocabulary especially adjective. But in test, students have a little bit difficulties in 
comparison degree of adjective. Students still doubt to add -er after the adjective or using more. Actually it can be solved, when they have study hard and do more practice.

Then, statement related to grammar is 'I can mastery the past form such as gowent-gone. Students gave agree respond toward this statement. It means that students did not have problem related to the past tense. But sometimes students still doubt when they faced questions. The result of the test showed that students have good ability in past tense. Just a little student who could not make different about past tense. It is showed by the result of the test, students could answer the questions. But there are some students who still have mistake about this one.

\section{Pronunciation}

After analyzing the data, writer got the result of the questionnaire as stated in table 3 below:

Table 3. Result of questionnaire about pronunciation

\begin{tabular}{|c|c|c|c|}
\hline $\begin{array}{l}\text { Score } \\
\text { interv }\end{array}$ & Category & $\begin{array}{c}\text { Frequenc } \\
\mathrm{y}\end{array}$ & $\begin{array}{l}\text { Perce } \\
\text { ntage }\end{array}$ \\
\hline$\geq 19$ & $\begin{array}{c}\text { Strongly } \\
\text { agree }\end{array}$ & 6 & 2.94 \\
\hline $15-18$ & Agree & 17 & 41.18 \\
\hline $11-14$ & $\begin{array}{c}\text { Undecide } \\
\text { d }\end{array}$ & 9 & 52.94 \\
\hline $7-10$ & Disagree & 2 & 2.94 \\
\hline$\leq 6$ & $\begin{array}{l}\text { Strongly } \\
\text { disagree }\end{array}$ & 0 & 0 \\
\hline & otal & 34 & 100 \\
\hline
\end{tabular}

From the questionnaire, it can be known that student's problems in mastery vocabulary also influenced by pronunciation. Pronunciation of a word in English is different to the written form of the word. Students gave respond agree toward the statement about pronunciation. For example the statement 'I am difficult to understand and to make differences between vocabularies such as wise, wish, twist and twist. So, it showed that the students do not have problem related to pronunciation.

3. Spelling

Table 4. Result of questionnaire about spelling

\begin{tabular}{|c|c|c|c|}
\hline $\begin{array}{c}\text { Score } \\
\text { interva } \\
1\end{array}$ & Category & $\begin{array}{c}\text { Frequenc } \\
\mathrm{y}\end{array}$ & $\begin{array}{c}\text { Percentag } \\
\text { e }\end{array}$ \\
\hline$\geq 22$ & $\begin{array}{c}\text { Strongly } \\
\text { agree }\end{array}$ & 1 & 2.94 \\
\hline $18-21$ & Agree & 14 & 41.18 \\
\hline $14-17$ & $\begin{array}{c}\text { Undecide } \\
\mathrm{d}\end{array}$ & 18 & 52.94 \\
\hline $10-13$ & Disagree & 1 & 2.94 \\
\hline$\leq 9$ & $\begin{array}{l}\text { Strongly } \\
\text { disagree }\end{array}$ & 0 & 0 \\
\hline & otal & 34 & 100 \\
\hline
\end{tabular}

From the table, it can be known that students' problem in vocabulary also influenced by spelling. It can be known from their respond when they ask to spell vocabularies from the unarranged letters. Actually to spell, English vocabulary correctly is more difficult than in Indonesian. Thus, English vocabularies have different pronunciation to the written form. It is one of the reasons that make students are difficult to spell to new vocabulary when they listen to the new vocabulary.

The result of the test related to grammar can be seen in the following table: 
Table 5. Result of test about grammar

\begin{tabular}{cll} 
No & Category & Percentage \\
1 & Very good & $14.70 \%$ \\
2 & Good & $82.35 \%$ \\
3 & Fair & $2.95 \%$ \\
4 & Poor & 0 \\
Total & & $100 \%$ \\
\hline
\end{tabular}

There were ten questions about grammar. From the result of the test, in grammar, some students' respond are difficulties in grammar related to past tense. From questions, it can get be known that students answered right in responding to the vocabularies related to verb tense. Others answered inappropriate. A student answered past form of write-writed. Actually the correct one is wrote-written. From questions about comparison degree, students are correct in answered comparison degree. But, in comparative degree, some students have mistake in adjective such as 'clever'. It should be cleverer for comparative degree and cleverest for superlative. Some of students answered 'more clever'. Other mistake is in using 'the' for superlative.

Then, the result of the test related to spelling can be explained through the table below

Table 6. Result of test about spelling and meaning

\begin{tabular}{cll}
\hline No & Category & Percentage \\
1 & Very good & $20.59 \%$ \\
2 & Good & $79.41 \%$ \\
3 & Fair & 0 \\
4 & Poor & 0 \\
Total & & $100 \%$ \\
\hline
\end{tabular}

In spelling, students are asked to spell the vocabulary correctly. In meaning, students are asked to match the vocabularies. Some students still have problems in defining the meaning of new vocabularies. It means that they still have difficulties in mastery vocabularies. They are difficult to find the meaning of new vocabularies. Matching the words to the synonyms of the words are categorized an easy activity to recognizing meaning of vocabulary. Students have a nice activity when they do matching the words to the synonyms. Students can do this activity well. They can match the words to the synonyms correctly. Then, students also arrange the unarranged letters to be a new vocabulary. They also can do this activity. The students can find as many as possible vocabularies from the unarranged words. For instance the letters are: c-a-p-o-m-n-y. The students can make vocabularies from the unarranged letters are: can, camp, nap, pan, man, map, any, a, an, may, no, pay.

The factors that influenced students' mastery of vocabulary are outside and inside factors. The outside factor is such as environment. For example environment does not support students to study or to practice. Students do not have friends or family that they can share of talk to them. So, students do not have place to share their ideas. Then, the inside factor is such as practice or personality of the students. They are brave or not to speak or practice in front of many people. Then, other inside factor is ashamed. Students sometimes fell ashamed to speak.

\section{CONCLUSION}

From the findings and discussion, it can be concluded that students' difficulties in vocabulary mastery are caused by 
grammar. In grammar, some students have difficulties in comparison degree and past tense. In comparison degree is especially in comparative degree and superlative degree. Other difficulties are caused by meaning of the vocabularies.

\section{REFERENCES}

Ahmadi, M. R, Ismail, H.N, Abdullah, M.K.K. 2012. Improving vocabulary learning in toreign language learning through reciprocal teaching strategy. International Journal of Learning\& Development. Vol 2, No 6, pp:186-201

Arikunto, Suharsimi. 2006. Prosedur Penelitian. Yogyakarta:Rineka Cipta

Best, John W and James W Kahn. 1995. Research in Education. New Delhi: Prentice-Hell

Cameron, Lynne. 2001. Teaching Language to Young Learners Cambridge Language Teaching University. Cambridge: Cambridge University Press

Faraj, Avan, K. A. 2015. Effective strategies for turning vocabulary into productive vocabulary in EFL context. Journal of Education and Practice. Vol 6, No 27, pp:10-19

Gay, L.R and P. Airasian 2000. Educational Research: Competencies for Analysis and Application (6th edition). New Jersey: Prentice Hall

Hudson, T. 2007. Teaching Second Language Reading. Oxford: Oxford University Press

Kamil, M., \& Hiebert,E. 2005. Teaching and learning vocabulary: Perspectives and persistent issues
Ling, Y. C, C. S. Tong \& N. Y. Jin. 2012. Evaluating the ESL Reading Texts for Intermediate Learners of English from the Perspective of Students. Global Journal of Human Social Science, Vol. 12, Issue. 7, pp: 54-60

McCarthy, M. 1990. Vocabulary Oxford O.U.P

Nagy, W. 1997. On the role context in first and second language vocabulary learning in N. Schmitt \& $\mathrm{M}$. McCathy (Eds) Vocabulary: Description, Acquisition and Pedagory.

Nation, I. S. P 1990. Teaching and Learning Vocabulary. Mass: Heinle \& Heinle

Sugiyono. 2010. Metode Penelitian Pendekatan Kuantitatif, Kualitatif dan $R \& D$. Bandung: Alfabeta

Wilkins, David A. 1972. Linguistics in Language Teaching. Cambridge: MIT Press 